\title{
MAATILOJEMME HOIDON JATKUVUUS JA NS. MAALTAPAKO
}

\author{
Antti Mäki, Maire Honkanen ja Matti Räsänen \\ Helsingin Yliopiston maanviljelystalouden laitos
}

Saapunut 19. 11. 1959

Taalainmaalla Ruotsissa sijaitsevassa Gagnefin kunnassa suoritetussa tutkimuksessa (3) on todettu, että vuoden 1944 tilastossa esiintyvällä 1086 viljelmällä oli v. 1951-52 ainoastaan 492 aktiivista viljelijää. Kunnassa oli mainittuna vuonna 267 tilastaan luopunutta viljelijää, joiden työtä ei kukaan ole jatkanut. Lisäksi aikoi lähiaikoina luopua tilastaan 160 sellaista viljelijää, joiden työtä eivät oman perheen jäsenet jää jatkamaan. Aktiivisten viljelijöiden lukumäärän arvioitiin olevan 1960-luvun alussa n. 300 ja v. 1975 alle 100.

Kun ns. maaltapaon seurauksena on samanlaisia ilmiöitä odotettavissa myös Suomessa, suoritettiin Valtion luonnontieteellisen toimikunnan myöntämin varoin Helsingin Yliopiston maanviljelystalouden laitoksen toimesta v. 1957 tiedustelu, jonka tarkoituksena oli selvittää maaltapaon vaikutusta viljelmiemme hoidon jatkuvuuteen. Tiedustelulomake lähetettiin vuoden 1950 yleisen maatalouslaskennan aineistosta ositettua satunnaisotantaa käyttäen saaduille, yksityisten viljelyksessä oleville, vähintään 2 peltohehtaaria käsittäville tilastoviljelmille, joita oli n. $10000 \mathrm{kpl}$. Vastauksia saatiin $4446 \mathrm{kpl}$. eli $44.2 \%$ lähetettyjen tiedustelujen määrästä. Tilastoviljelmien valintaperusteet on aikaisemmin julkaistu (5). Tutkimusaineiston jäädessä alkuperäisten tilastoviljelmien määrää pienemmäksi ei tuloksia esitetä maanviljelysseuroittain, vaan neljänä tutkimusalueena, joihin eri maanviljelysseurat on ryhmitelty seuraavasti:

Etelä-alue (E):

Uudenmaanläänin mvs., Nylands sv. lbs., Varsinais-Suomen mvs., Finska hushållningssällskapet, Hämeenläänin ja Kymenlaakson mvs.

Keski-alue (K):

Satakunnan, Hämeen-Satakunnan, Itä-Hämeen, Länsi-Karjalan, Mikkelin läänin, Kuopion, Keski-Suomen, Etelä-Pohjanmaan mvs., Österbottens sv. lbs. ja Keski-Pohjanmaan mvs.

Pohjois-alue (P):

Oulun läänin talousseura, Kajaanin ja Pohjois-Karjalan mvs. 
Lapin alue $(\mathrm{L})$ :

Peräpohjolan mvs. ja Lapin maatalousseura.

Viljelmät on ryhmitelty neljään suuruusluokkaan peltoalan mukaan: I (210 ha), II (10-25 ha), III (25-50 ha) ja IV (yli 50 ha peltoa).

\section{Viljelijöiden ikäsuhteet}

Tutkittaessa nykyisten viljelijöiden ikäsuhteita katsottiin viljelijäksi isäntä ja sellaisen puuttuessa emäntä tai naispuolinen viljelijä. Viljelijöiden jakaantuminen ikäluokkiin koko maassa ja eri alueilla esitetään seuraavassa asetelmassa.

\begin{tabular}{crrrrc}
$\begin{array}{c}\text { Ikä } \\
\text { v. }\end{array}$ & E & \multicolumn{2}{c}{$\%$ eri alueilla } & \multicolumn{2}{c}{$\begin{array}{c}\text { Koko maa } \\
\text { keskim. \% }\end{array}$} \\
-20 & 0.1 & 0.2 & 0.2 & - & 0.1 \\
$20-30$ & 3.0 & 2.5 & 1.8 & 2.0 & 2.5 \\
$30-40$ & 14.0 & 14.6 & 12.4 & 8.6 & 13.8 \\
$40-50$ & 26.1 & 27.3 & 28.5 & 23.0 & 27.0 \\
$50-60$ & 29.6 & 29.5 & 29.4 & 30.8 & 29.6 \\
$60-70$ & 22.0 & 18.5 & 20.5 & 21.9 & 19.8 \\
$70-$ & 5.2 & 7.4 & 7.2 & 13.7 & 7.2
\end{tabular}

Tutkimus osoittaa, että kahdella eteläisimmällä tutkimusalueella viljelijöiden jakaantumisessa ikäluokkiin on vain vähäisiä eroja. Siirryttäessä E- ja K-alueilta P-alueelle vähenee alle 40-vuotiaiden viljelijöiden määrä noin $3 \%$. Lapin alueella kuuluu viljelmien päämiehistä edellisiä suurempi osa vanhoihin ikäluokkiin, nuorten viljelijöiden puuttuessa lähes kokonaan. Yli 50-vuotiaita viljelmän päämiehiä on keskimäärin koko maassa runsaasti puolet, eniten L-alueella, missä niitä on $2 / 3$ kaikista viljelijöistä.

Seuraavassa asetelmassa esitetään viljelijöiden keskimääräinen ikä alueittain ja viljelmäsuuruusluokittain.

\begin{tabular}{cccccc}
\multicolumn{7}{c}{ Ikä vuosia eri viljelmäsuuruusluokissa } & \multicolumn{2}{c}{ Koko maa } \\
Alue & I & II & III & IV & keskim. v. \\
E & 52.1 & 49.9 & 51.8 & 52.0 & 51.1 \\
K & 50.7 & 51.0 & 51.3 & 50.5 & 50.8 \\
P & 51.3 & 53.4 & 54.1 & 52.4 & 52.1 \\
L & 53.1 & 58.1 & 61.2 & - & 53.9 \\
Koko maa & 51.2 & 51.2 & 51.8 & 51.4 & 51.3
\end{tabular}

Viljelijöiden ikä koko maassa on keskimäärin 51.3 vuotta. Alueittain tarkasteltaessa keski-ikä on korkein Lapissa. Viljelmän koon vaikutusta on havaittavissa vain maan pohjoisosassa, missä keski-ikä kohoaa viljelmäkoon kasvaessa. Tarkasteltaessa viljelijän keski-ikää maanviljelysseuroittain voidaan huomata, että Ealueeseen kuuluvissa ruotsinkielisissä maanviljelysseuroissa keski-ikä on noin kaksi vuotta korkeampi kuin saman alueen suomenkielisissä maanviljelysseuroissa. Vilje- 
lijöiden keski-ikä kasvaa yleensä, mainittuja ruotsinkielisiä maanviljelysseuroja lukuunottamatta, pohjoista ja itää kohden siirryttäessä. P-alueen viljelijät ovat keskimäärin vuoden vanhempia ja L-alueella lähes kolme vuotta vanhempia kuin viljelmän päämiehet eteläisimmillä alueilla.

\section{Viljelijän käsitys tilan tulevasta hoidosta}

Tutkimuksen päätarkoituksena oli selvittää kuinka tilan hoito on suunniteltu järjestettäväksi nykyisen viljelijän siitä luovuttua. Tähän kysymykseen oli $21.1 \%$ mukana olevista viljelmistä jättänyt vastaamatta, suurimmalta osalta siksi, että nuorimmilla viljelijöillä ei ollut lainkaan perillisiä tai ne olivat vielä pieniä. Taulukossa 1 esitetään viljelijän käsitys tilan hoidosta tulevaisuudessa.

Sukulaisille aikoo L-alueella jättää tilansa $88.1 \%$ tutkimuksessa mukana olevista viljelijöistä. K-alueella vastaava luku on 87.1 ja kahdella muulla alueella tätä pienempi. Toiseksi tärkeimpänä ryhmänä esiintyy tilan myyminen, jota E- ja P-alueilla pitää mahdollisena noin $13 \%$ viljelijöistä, muilla alueilla huomattavasti

Taulukko 1. Tilan hoito tulevaisuudessa eri alueilla ja keskimäärin koko maassa.

Table 1. Future management of the farm in different areas and average in the country as a whole.

\begin{tabular}{|c|c|c|c|c|c|}
\hline $\begin{array}{c}\text { Tilan hoito } \\
\text { Farm management }\end{array}$ & E & $\begin{array}{c}\% \mathrm{e} \\
\% \text { in } d \\
\mathrm{~K}\end{array}$ & $\begin{array}{l}\text { lueilla } \\
\text { ent areas } \\
\text { P }\end{array}$ & L & $\begin{array}{c}\text { Koko maa } \\
\text { keskim. \% } \\
\text { Whole country } \\
\text { average } \%\end{array}$ \\
\hline $\begin{array}{l}\text { Luovutetaan sukulaisille } \ldots \ldots \ldots \ldots \ldots \ldots \ldots \\
\text { Will be handed over to relatives }\end{array}$ & 82.7 & 87.1 & 82.4 & 88.1 & 85.4 \\
\hline $\begin{array}{l}\text { Liitetään toiseen tilaan } \ldots \ldots \ldots \ldots \ldots \ldots \ldots \ldots \\
\text { Will be combined with another farm }\end{array}$ & 0.1 & 0.2 & 0.2 & 1.0 & 0.2 \\
\hline $\begin{array}{l}\text { Myydään } \ldots \ldots \ldots \cdots \cdots \cdots \cdots \cdots \cdots \cdots \cdots \\
\text { Will be sold }\end{array}$ & 12.8 & 8.4 & 12.6 & 7.1 & 10.0 \\
\hline $\begin{array}{l}\text { Myydaän tai annetaan vuokralle } \ldots \ldots \ldots \ldots \ldots \\
\text { Will be sold or let }\end{array}$ & 1.4 & 0.8 & 0.4 & - & 0.9 \\
\hline $\begin{array}{l}\text { Annetaan vuokralle } \quad \ldots \ldots \ldots \ldots \ldots \ldots \ldots \ldots \\
\text { Will be let }\end{array}$ & 2.1 & 1.8 & 1.3 & 0.5 & 1.7 \\
\hline $\begin{array}{l}\text { Jätetään viljelemättä } \ldots \ldots \ldots \ldots \ldots \ldots \ldots \ldots \ldots \\
\text { Farming neglected }\end{array}$ & 0.9 & 1.7 & 3.1 & 3.3 & 1.8 \\
\hline
\end{tabular}

pienempi osa. Yllättävän harvat suunnittelevat tilansa liittämistä toiseen tilaan, vain $0.1-0.2 \%$ muilla alueilla ja Lapissa $1.0 \%$ viljelijöistä. Kaikilla alueilla ovat viljelemättä jättämistä osoittavat luvut suuremmat kuin toiseen tilaan liittämistä osoittavat. Kuten taulukosta 1 käy ilmi, aiotaan eniten tiloja jättää viljelemättä Lapissa, $3.3 \%$. Autotiotilatoimikunnan suorittaman tutkimuksen (1) mukaan autioiksi jätettyjä tiloja esiintyy runsaimmin Oulun läänin talousseuran alueella, joka kuuluu P-alueeseen. Maaltapako-tutkimuksen suoritustavasta johtuen ei kaik- 
kia jo autioituneita tiloja voitu tässä yhteydessä saada selville. Tutkimuksen perusteella voidaan kuitenkin todeta, että nykyisten viljelijöiden käsityksen mukaan sukupolven vaihtuminen tiloilla tuskin tulee aiheuttamaan tavallisuudesta poikkeavia toimenpiteitä.

Tapauksissa, joissa tila on tarkoitus luovuttaa sukulaisille, on selvitetty myös eri sukulaisryhmien osuudet. Nämä esitetään seuraavassa asetelmassa.

\begin{tabular}{|c|c|c|c|c|c|}
\hline \multirow[t]{2}{*}{ Tila luovutetaan } & \multicolumn{4}{|c|}{$\%$ eri alueilla } & \multirow{2}{*}{$\begin{array}{l}\text { Koko maa } \\
\text { keskim. \% }\end{array}$} \\
\hline & E & $\mathrm{K}$ & $\mathrm{P}$ & $\mathbf{L}$ & \\
\hline Pojalle $\ldots \ldots \ldots \ldots$ & 66.8 & 58.3 & 50.6 & 46.0 & 58.5 \\
\hline Tyttärelle (vävylle).. & 11.2 & 8.5 & 7.5 & 3.2 & 8.7 \\
\hline Muille sukulaisille .. & 3.1 & 3.2 & 1.0 & 1.6 & 2.8 \\
\hline Jaetaan perill. kesken & 18.9 & 30.0 & 40.9 & 49.2 & 30.0 \\
\hline
\end{tabular}

Useimmissa tapauksissa tila halutaan luovuttaa yhdelle pojalle. E-alueella on pojan osuus sukulaisille luovutettavien tilojen lukumäärästä $66.8 \%$, muilla alueilla vähemmän. Vain maan pohjoisimmassa osassa luku on alle $50 \%$. Samaan suuntaan muuttuu myös tyttärelle (ja vävylle, jos tytär on naimisissa) luovutettavien tilojen suhteellinen määrä. Yhteensä yhdelle lapselle luovutettavien tilojen osuus vaihtelee $78.0 \%$ :sta (E-alue) $49.2 \%$ :iin (L-alue). Koko maan keskiarvo on $67.2 \%$. Alueittain havaitaan vallitsevan päinvastaisen suunnan niiden tilojen suhteellisissa määrissä, jotka jaetaan perillisten kesken. E-alueella on viimeksi mainittuja $18.9 \%$, mutta L-alueella peräti $49.2 \%$ tiloista. Tutkimuksessa mukana olevista viljelmistä on E-alueella $32.3 \%$ sellaisia, joilla on peltoa vähintään 25 ha, K-alueella $13.9 \%$, P-alueella 7.6 ja L-alueella $1.9 \%$. Näin ollen siis pienten viljelmien osuuden lisääntyessä kasvaa halu niiden jakamiseen etelä-Suomesta Lappiin siirryttäessä. Tapausten harvalukuisuuden vuoksi on voitu tutkia suuruusluokittain vain tilan luovuttamista pojalle. Siihen ei viljelmän koolla näytä olevan vaikutusta.

Tutkimuksen yhteydessä tiedusteltiin myös, aikooko viljelijä luopua lähivuosina tilan hoidosta. Koska kysymyksessä on tulevaisuudessa tapahtuva toimenpide, ei aikarajoitusta voitu asettaa täsmällisemmäksi. E-alueella on $15.6 \%$, K-alueella 17.9, P-alueella 18.7, L-alueella 27.6 ja keskimäärin koko maassa $18.0 \%$ sellaisia viljelijöitä, jotka aikovat lähivuosina luopua tilan hoidosta. Viimeisten viiden vuoden kuluessa tilan hallintaansa saaneiden viljelijöiden osuus vaihtelee eri tutkimusalueilla $4.0 \%$ :sta $8.1 \%$ :iin. Jos mainittuihin lukuihin verrataan tilasta lähivuosina luopumista suunnittelevien määrää, se vaikuttaa varsin korkealta. Eri kokoisilla tiloilla näyttää viljelijän tehtävästä luopuvien määrä vaihtelevan epäsäännöllisesti kuitenkin niin, että E- ja K-alueilla suurimmilla tiloilla niistä luopuvia on vähemmän kuin muilla. Pääosan eli lähes $60 \%$ tilasta luopuvien ryhmästä muodostavat yli 60 -vuotiaat viljelijät. Runsaat $80 \%$ luopuvista kuuluu yli 50 vuotiaisiin.

Suunniteltaessa tilasta luopumista ovat tärkeimpinä tekijöinä taloudelliset syyt sekä viljelijän ikä. Vanhuuden, huonon terveyden ja sairauden osuudet keskimäärin koko maassa muodostavat noin $70 \%$ tilasta luopumisen syistä. 
Tutkimuksessa on selvitetty kahta eri tietä, onko odotettavissa, että joku viljelijäperheen jäsenistä tai sukulaisista jatkaa nykyisen viljelijän työtä. Edellä on selostettu nykyisen viljelijän mielipide siitä, kuinka hän on suunnitellut työtänsä jatkettavan. Toisaalta voidaan lähteä viljelijäperheen lapsista, heidän koulutuksestaan ja mahdollisesti jo suorittamastaan ammatinvalinnasta. Seuraavassa asetelmassa esitetään viljelijäperheiden jakaantuminen lapsiluvun mukaan koko maassa ja eri alueilla.

\begin{tabular}{|c|c|c|c|c|c|}
\hline Lapsia & & $\%$ er & seilla & & Koko maa \\
\hline kpl & E & K & $P$ & L & keskim. \% \\
\hline 0 & 11.1 & 9.9 & 6.3 & 6.9 & 9.5 \\
\hline 1 & 13.1 & 9.9 & 6.9 & 5.8 & 10.0 \\
\hline 2 & 24.3 & 18.7 & 12.6 & 5.8 & 18.5 \\
\hline 3 & 21.0 & 18.3 & 15.4 & 14.6 & 18.3 \\
\hline 4 & 12.4 & 15.1 & 15.4 & 8.8 & 14.1 \\
\hline 5 & 6.9 & 10.4 & 13.1 & 15.7 & 10.2 \\
\hline 6 & 4.0 & 6.8 & 8.5 & 10.7 & 6.6 \\
\hline 7 & 2.5 & 4.1 & 6.8 & 12.6 & 4.6 \\
\hline 8 & 2.0 & 3.0 & 4.7 & 6.1 & 3.2 \\
\hline 9 & 1.2 & 1.9 & 3.8 & 4.2 & 2.1 \\
\hline $10-11$ & 1.0 & 1.6 & 3.9 & 6.9 & 2.1 \\
\hline $12-14$ & 0.5 & 0.2 & 2.4 & 1.5 & 0.7 \\
\hline $15-$ & - & 0.1 & 0.2 & 0.4 & 0.1 \\
\hline
\end{tabular}

Lapsettomien perheiden osuus on asetelman mukaan suurin etelä-Suomessa, $11.1 \%$, ja pienin P-alueella, $6.3 \%$. On otettava huomioon, että lukuihin sisältyvät myös nuoret viljelijäperheet, joista osa tulee lopullisesti kuulumaan johonkin muista ryhmistä. Kun tutkimuksen mukaan kolmella eteläisimmällä alueella ei viljelmän päämiehen ikäjakaantumassa ole havaittavissa kovin suuria eroja, on ilmeistä, että viljelijäperheiden lapsettomuus on yleisempää etelä- kuin pohjoisSuomessa. E-alueella esiintyy lapsettomuutta suhteellisesti eniten ruotsinkielisten maanviljelysseurojen alueilla.

E-alueella muodostavat suurimman ryhmän 2-lapsiset perheet. Mitä pohjoisemmaksi mennään, sitä useampilapsisten ryhmään kuuluu enemmistö viljelijäperheistä. L-alueen luvut eivät ole tässä suhteessa täysin verrattavissa muihin, koska viljelijöiden keski-ikä on siellä noin kolme vuotta korkeampi kuin etelä- ja keski-Suomessa. Viljelijäperheiden keskimääräinen lapsiluku käy selville seuraavasta asetelmasta.

Keskimääräinen lapsiluku viljelmää kohden ${ }^{1}$ ).

$\begin{array}{llllc}\text { E } & \text { K } & \text { P } & \text { L } & \text { Koko maa } \\ 2.9 & 3.4 & 4.5 & 5.0 & 3.5\end{array}$

1) Jos tilalla on useampia viljelijäperheitä, on näiden lasten lukumäärät laskettu yhteen. 
Asetelmasta voidaan havaita, että keskimääräinen lapsiluku kașvaa jatkuvasti siirryttäessä E-alueelta pohjoiseen päin. L-alueella on 2.1 lasta enemmän kuin etelä-Suomen viljelijäperheissä.

Tutkimuksen yhteydessä tiedusteltiin yksityiskohtaisesti myös lasten koulutusta. Eri oppilaitoksissa olevien sekä koulunsa tai opintonsa päättäneiden lasten määrät koko lapsilukuun verrattuina esitetään seuraavassa asetelmassa.

\section{Oppilaitos}

Kansakoulussa olevia

Kansakoulun suorittaneita

Kansanopisto tai kansankorkeakoulu

Maatalous- tai metsäammattikoulu

Kotitalous-, emäntä-, puutarha- tai karjanhoito-

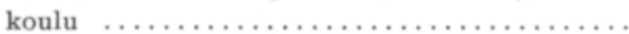

Seminaari tai muu ammattikoulu $\ldots \ldots \ldots \ldots \ldots$

Oppikoulussa olevia

Oppikoulun suorittaneita

Yliopisto tai korksakoulu

Muu oppilaitos

$\begin{array}{ccc} & \% & \text { eri alueilla } \\ \text { E } & \mathrm{K} & \mathrm{P}\end{array}$

\section{5}

23.3

4.9

5.2

2.5

5.4

8.8

3.1

3.6

1.6
21.7

28.8

5.1

3.1

22.8

29.3

4.4

2.3

3.3

3.6

3.7

4.1

1.4

1.3

0.2
Koko maa

L keskim. \%

$16.4 \quad 21.0$

$35.9 \quad 28.4$

$4.1 \quad 4.9$

$2.4 \quad 3.3$

2. 6

3.1

4.5

6.3

2.5

2.4

0.9

Koska ammattikoulut ja niihin verrattavat, samoin kuin korkeakoulutkin edellyttävät kansa- tai oppikoulun suorittamista, kiinnitettiin tutkimuksessa huomiota vain siihen oppilaitokseen, missä kukin viljelijäperheen lapsista tiedustelun hetkellä oli tai minkä oppikurssin hän viimeksi oli suorittanut. Näitä lukumääriä on verrattu viljelijäperheen lasten kokonaismäärään, mihin sisältyvät siis myös kouluikäisiä nuoremmat. Pelkästään kansakoulun kurssin suorittaneita oli Ealueella vajaa neljäs osa lasten lukumäärästä. Siirryttäessä pohjoiseen päin lisääntyy tämä määrä niin, että L-alueella se on yli kolmanneksen lasten lukumäärästä. Kansanopiston tai kansankorkeakoulun, samoin kuin eri ammattikoulujen suorittaminen on vähäistä kaikilla tutkimusalueilla. Erityisesti kiinnittää huomiota, että maa- tai metsäammattikoulun sekä seminaarin ja muiden ammattikoulujen käyminen on tullut kysymykseen suhteellisesti harvemmissa tapauksissa P-alueella kuin muilla seuduilla. Oppikouluun sekä korkeakouluihin on tullut viljelijäperheiden lapsia suhteellisesti eniten maan eteläosasta ja P-alueelta vähemmän kuin muualta.

\section{Tilan säilyminen saman perheen viljelyksessä}

Koulunsa tai opintonsa päättäneiden kohdalla selvitettiin maataloudessa (ja siihen liittyvässä kotitaloudessa) kotona ja muualla toimivien, samoin muihin ammatteihin siirtyneiden poikien ja tyttärien määrät. Tutkimuksessa otettiin huomioon myös koulussa olevien lasten aikomus jäädä maatalouden palvelukseen. Seuraavassa asetelmassa esitetään viljelmien alueittainen jakaantuminen ryhmiin sen mukaan kuinka varmalta, edellä mainitut seikat huomioon ottaen, näyttää tilan säilyminen saman perheen viljelyksessä seuraavan sukupolven aikana. 


$\begin{array}{ccccc}\text { E } & \text { eri alueilla } & & & \begin{array}{r}\text { Koko maa } \\ \text { K }\end{array} \\ & \mathrm{K} & \mathrm{P} & \mathrm{L} & \text { keskim. } \%\end{array}$

Viljelijäperheen lapsista toimi maatalouden palveluksessa

a) kotona:

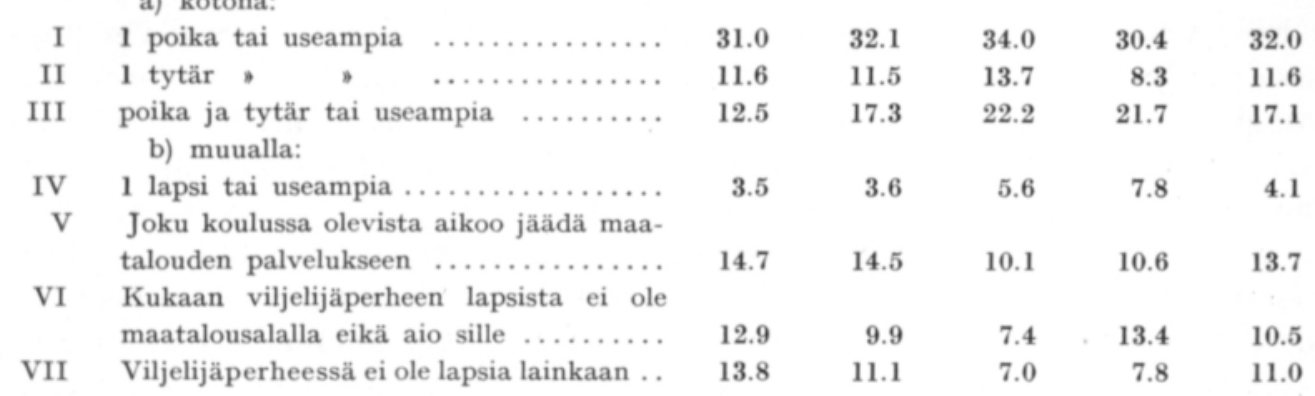

Asetelmassa ryhmiin I, II, III ja suurimmalta osalta myös ryhmään V kuuluvilla tiloilla tulee todennäköisesti nykyisen viljelijän työtä jatkamaan joku hänen perheensä jäsenistä. Ryhmään IV kuuluvilla tiloilla on siihen myös mahdollisuus, mutta läheskään aina eivät viljelijöiden lapset palaa enää kotitilaansa hoitamaan, jos he jo ovat sijoittuneet muualle vaikkapa vastaavanlaisiinkin tehtäviin. Erityisesti tilan ollessa pieni tai viljelijän joutuessa lunastamaan useita sisarosuuksia voi kotitilan haltuun ottaminen tuottaa vaikeuksia. Ryhmään VI kuuluvien tilojen kohdalla on erittäin vähän todennäköistä, että joku perheen jäsen jatkaisi nykyisen viljelijän työtä, sillä melko harvoin muun ammatin hankkinut nuoriso palaa kotitilalleen.

Edellä olevasta asetelmasta ilmenee, että kaikilla tutkimusalueilla noin 1/3:lla viljelmistä tulee nykyisen viljelijän poika jatkamaan isänsä työtä kotitilalla. Lisäksi voidaan melkoisella varmuudella päätellä, että E-alueella noin $55 \%$, K- ja Lalueilla noin $60 \%$ ja P-alueella noin $70 \%$ tiloista (ryhmät I-III) tulee pysymään samaan perheeseen kuuluvan viljelyksessä seuraavan sukupolven aikana.

Etelä- ja Keski-alueilla vähämerkityksiseen IV-ryhmään kuuluvista tiloista on oletettavasti pieni osa sellaisia, joille joku perheen lapsista palaa hoitamaan tilaa. Pääosan tästä ryhmästä muodostavat maatiloille emänniksi menneet talojen tyttäret, joten kotitilan hoitaminen on heille useimmiten mahdollista vain, jos se sijaitsee lähellä nykyistä asuinpaikkaa.

Viidennen ryhmän muodostavista viljelmistä on ilmeisesti suurin osa sellaisia, joilla poika tai tytär ottaa tilan haltuunsa. Tämän ryhmän vastaukset perustuvat kuitenkin tulevaisuuden suunnitelmiin, joten niitä ei voida pitää lopullisina.

Ryhmiin VI ja VII kuuluvat tilat ovat pääasiassa sellaisia, joilla seuraavan sukupolven viljelijä ei ole nykyisen viljelijäperheen jäsen. Koska mainittuihin ryhmiin sisältyy myös nuoria viljelijöitä, joilla ei ole lapsia tai lapset eivät ole vielä kouluikäisiä, tulee osa näiden ryhmien tiloista lopullisesti kuulumaan johonkin muuhun ryhmään. Suurin osa nuorista viljelijöistä on kuitenkin jättänyt vastaamatta tähän kysymykseen, eikä siis sisälly mihinkään mainituista ryhmistä.

Ottaen huomioon eri tilaryhmiä koskevat seikat voitaneen olettaa, että ryhmien I-V lukumäärät yhteensä osoittavat kuinka suuri osa viljelmistä korkein- 
taan tulee säilymään seuraavan sukupolven aikana nykyisen viljelijän perheeseen kuuluvan viljelyksessä. Kun mainittuja prosenttilukuja verrataan sukulaisille luovutettavien tilojen määriin (taulukko 1), voidaan todeta, että P-aluetta lukuun ottamatta on sukulaisille luovutettavien tilojen määrä noin $10 \%$ suurempi kuin niiden viljelijäperheiden, joissa tilan pysyminen saman perheen jäsenellä seuraavassa sukupolvessa on todennäköistä. Osa sukulaisille luovutettavista tiloista tullaan siis ilmeisesti myymään tai antamaan vuokralle. Vain P-alueella, missä perheen jäsenet tutkimuksen mukaan ovat kiinnostuneempia kotitilan viljelemiseen kuin muilla alueilla, on sukulaisille luovutettavia tiloja vähemmän kuin niiden viljelyyn halukkaita. Oletettavasti suurimpana syynä tähän ovat alueen muiden ammattien tarjoamat vähäiset mahdollisuudet. Sen sijaan verraten pienellä Ealueella, missä sijaitsee suuri osa maamme teollisuudesta ja kaupunkeja sekä muita taajamia on suhteellisesti enemmän kuin muualla Suomessa, on vähiten kotitilan viljelyyn halukasta nuorisoa.

\section{Tilalta siirtyneiden lasten määrät ja ammatti}

Tilalta muualle maa- ja metsätalouden sekä muiden elinkeinojen palvelukseen siirtyneiden lasten osuudet koko lapsiluvusta esitetään alueittain ja viljelmäsuuruusluokittain seuraavassa asetelmassa.

\begin{tabular}{cccccc} 
Alue & \multicolumn{3}{c}{$\%$ eri viljelmäsuuruusluokissa } & \multicolumn{2}{c}{ Koko maa } \\
& I & II & III & IV & keskim. \% \\
E & 27.5 & 19.7 & 16.0 & 21.5 & 21.3 \\
K & 19.2 & 20.0 & 18.6 & 18.2 & 19.4 \\
P & 14.8 & 19.6 & 27.4 & 13.6 & 16.9 \\
L & 19.1 & 23.2 & 22.2 & - & 19.8
\end{tabular}

Edellä olevan asetelman luvut eivät ilmoita lopullisia muualle siirtyvien lasten määriä, koska vertailuperusteena on käytetty perheiden koko lapsilukua, mutta siirtyneiden määrä on tiedossa vain varttuneempien kohdalta. Suhteellisesti eniten on lapsia siirtynyt muualle E-alueella ja vähiten P-alueella. Ottaen huomioon, että etelä-Suomessa on viljelmää kohden laskettu lapsiluku huomattavasti pienempi kuin muualla maassa (asetelma s. 31) ja tutkimuksen mukaan kuuluu pieniin viljelmäsuuruusluokkiin muilla alueilla enemmän tiloja kuin E-alueella, voidaan maaltapaon suuruuden katsoa pääosaltaan riippuvan muiden elinkeinojen tarjoamista työtilaisuuksista.

Tarkasteltaessa alueittain eri kokoisilta viljelmiltä siirtyneiden lasten suhteellisia määriä havaitaan, että E-alueella on siirtymistä tapahtunut runsaimmin pienillä viljelmillä, joilla vain jotkut lapsista voivat päästä muiden ammattien ansiotasoa vastaaviin tuloksiin. Tilakoon kasvaessa on useammilla sisaruksista mahdollisuus suunnitella kotitilalle jäämistä. Suurimpien tilojen jakamista on vanhastaan kartettu, joten niillä suhteellisen suuri osa lapsista siirtyy muualle. Samaan suuntaan vaikuttavat myös paremmat koulunkäynti- ja opiskelumahdollisuudet. 
P-alueella, missä lapsiluku viljelmää kohden on $1.6 \mathrm{kpl}$. suurempi kuin Ealueella, näyttää tilakoolla olevan edelliseen verrattuna päinyastainen vaikutus, Tämä johtunee alueen muiden ansiomahdollisuuksien vähäisyydestä, jolloin suuri osa sisaruksista jakaa kotitilan ja hakeutuu pääasiassa metsätalouden piirissä talvisaikaan esiintyviin sivuansiotöihin. Suuremmilla viljelmillä, joita tutkimuksessa on tältä alueelta mukana verraten vähän, on paremmat mahdollisuudet lasten kouluttamiseen. Ammattitaitoisina ovat viljelijäperheidenkin lapset vähemmän sidottuja kotitilaansa ja lähiseutuun.

Muilla alueilla ei tutkimuksen mukaan viljelmän koolla ole selvää vaikutusta nuorison siirtymisen määrään.

Niiden koulunsa tai opintonsa päättäneiden lasten kohdalla, jotka eivät toimineet kotona maatalouden tai siihen liittyvän kotitalouden piirissä, tiedusteltiin mille aloille he ovat siirtyneet. Seuraavassa esitetään maa- ja metsätalouden ja toisaalta muiden elinkeinojen osuudet verrattuina siirtyneiden lasten koko lukumäärään.

\begin{tabular}{lccccc} 
& \multicolumn{3}{c}{$\%$ eri alueilla } & \multicolumn{3}{c}{ Koko maa } \\
& E & K & P & L & keskim. \% \\
Maa- ja metsätalous $\ldots \ldots \ldots$ & 17.3 & 25.2 & 27.3 & 26.9 & 23.9 \\
Mut elinkeinot $\ldots \ldots \ldots \ldots \ldots$ & 82.7 & $\mathbf{7 4 . 8}$ & $\mathbf{7 2 . 7}$ & $\mathbf{7 3 . 1}$ & $\mathbf{7 6 . 1}$
\end{tabular}

Asetelmasta havaitaan, että viljelijäperheiden muualle siirtyneistä lapsista on suurin osa sijoittunut maa- ja metsätalouden ulkopuolelle. Erityisen pieni on E-alueella muualle maatalouden palvelukseen, kuten maanviljelijöiksi, talon emänniksi ja maa- sekä metsätalouden työntekijöiksi siirtyneiden osuus kaikkien kotoa siirtyneiden lasten lukumäärästä. Muilla alueilla vastaava luku on 1/4 tai enemmän kaikista siirtyneistä.

Viljelmän koolla näyttää kotoa siirtyneiden lasten ammatinvalintaan olevan selvästi vaikutusta vain E-alueella, missä muihin ammatteihin sijoittuneiden suhteellinen määrä pienenee I:stä III:een suuruusluokkaan. Yli 50 peltohehtaarin tiloilla muiden ammattien osuus suurenee edellisiin verrattuna. Kuten aikaisemmin on mainittu, johtuu tämä lähinnä paremmista koulunkäynti- ja opiskelumahdollisuuksista, jolloin muille aloille viittaavat taipumukset pääsevät helpommin esille.

\section{Siirtymisen syyt}

Koska tiedustelu ei voinut tavoittaa viljelmältä siirtyneitä lapsia, tiedusteltiin viljelijöiltä, mikä heidän käsityksensä mukaan oli pääasiallisin syy tilalta siirtymiseen. Yhdistelmä esille tulleista syistä esitetään taulukossa 2 .

Kaikilla alueilla muodostaa maatalouden huono kannattavuus suurimman ryhmän nuorison tilalta siirtymisen syistä. Kahdella eteläisimmällä alueella tämän syyn on ilmoittanut runsas kolmannes viljelijöistä, kahdella pohjoisimmalla lähes puolet tähän vastanneista viljelijöistä. Lukuun ottamatta ryhmää "muut syyt», joka käsittää $\mathrm{mm}$. avioliiton solmimisen, terveydellisiä sekä vähemmän yleisiä 
Taulukko 2. Viljelijän käsitys siirtymisen syistä eri alueilla ja keskimäärin koko maassa.

Table 2. The farmer's view of the reasons for the exodus, tabulated by the different districts as an average for the country as a whole.

\begin{tabular}{|c|c|c|c|c|c|}
\hline \multirow[t]{2}{*}{$\begin{array}{l}\text { Siirtymisen syy } \\
\text { Reason for exodus }\end{array}$} & \multicolumn{3}{|c|}{$\begin{array}{l}\% \text { eri alueilla } \\
\% \text { in different areas }\end{array}$} & \multicolumn{2}{|c|}{$\begin{array}{c}\text { Koko maa } \\
\text { keskim. \% } \\
\text { Whole country }\end{array}$} \\
\hline & $\mathrm{E}$ & K & $\mathrm{P}$ & L & average $\%$ \\
\hline $\begin{array}{l}\text { Maatalouden huono kannattavuus } \ldots \ldots \ldots \ldots \ldots \\
\text { Poor profitableness of agriculture }\end{array}$ & 38.4 & 37.8 & 45.6 & 48.4 & 39.8 \\
\hline $\begin{array}{l}\text { Sivuansioiden puute } \ldots \ldots \cdots \cdots \cdots \cdots \cdots \cdots \cdots \cdots \cdots \cdots \cdots \\
\text { Lack of supplementary earnings }\end{array}$ & 1.1 & 5.6 & 2.9 & 1.9 & 3.9 \\
\hline $\begin{array}{l}\text { Raskas verotus } \\
\text { Heavy taxation }\end{array}$ & 6.0 & 5.8 & 4.9 & 0.6 & 5.4 \\
\hline $\begin{array}{l}\text { Haluttomuus tilan jakamiseen } \ldots \ldots \ldots \ldots \ldots \ldots \ldots \\
\text { Unwillingness to split up the farm }\end{array}$ & 21.0 & 24.2 & 23.0 & 18.9 & 22.9 \\
\hline $\begin{array}{l}\text { Tilan maat karuja, kivisiä tai veden vaivaamia } . . \\
\text { Farm lands barren, stony or water-logged }\end{array}$ & 0.8 & 2.1 & 3.6 & 0.6 & 1.9 \\
\hline $\begin{array}{l}\text { Työpäivän pituus, työn raskaus ja likaisuus .... } \\
\text { Length of working day, heavy and dirty nature of work }\end{array}$ & 9.5 & 9.3 & 6.5 & 6.9 & 8.8 \\
\hline $\begin{array}{l}\text { Virkistys- ja huvitilaisuuksien puute } \ldots \ldots \ldots \ldots \\
\text { Lack of recreational and entertainment facilities }\end{array}$ & 1.2 & 0.6 & - & - & 0.6 \\
\hline $\begin{array}{l}\text { Harrastuksen puute maataloutta kohtaan } \ldots \ldots \\
\text { Lack of interest in farming }\end{array}$ & 8.7 & 3.8 & 2.0 & 6.3 & 4.8 \\
\hline $\begin{array}{l}\text { Muut syyt } \ldots \ldots \ldots \ldots \ldots \ldots \ldots \ldots \ldots \ldots \ldots \ldots \ldots \ldots \ldots \ldots \\
\text { Other reasons }\end{array}$ & 13.3 & 10.8 & 11.5 & 16.4 & 11.9 \\
\hline
\end{tabular}

syitä, muodostaa haluttomuus tilan jakamiseen kaikilla tutkimusalueilla seuraavaksi suurimman ryhmän. Eri alueilla on tästä syystä siirtynyt nuorisoa muualle noin neljäs- tai viidesosalta tiloja. Varsin monet ovat pitäneet työpäivän pituutta, työn raskautta ja likaisuutta ratkaisevana tekijänä.

Tässä yhteydessä ei esitetä siirtymisen syitä viljelmäsuuruusluokittain, mutta voidaan kuitenkin mainita, että pieniltä ja keskikokoisilta tiloilta puuttuu sivuansioita, ja raskas verotus on ilmoitettu siirtymisen syyksi pienillä tiloilla useammin kuin suurilla. Edellistä selvemmin käy ilmi, että haluttomuus tilan jakamiseen on suurempi pienillä kuin kookkailla viljelmillä. Vielä voidaan mainita, että harrastuksen maataloutta kohtaan ilmoitetaan yleensä vähenevän tilakoon kasvaessa.

\section{Yhteenveto}

Tutkimus perustuu tiedusteluun, joka lähetettiin v. 1957 postitse n. 10 000:lle vähintään 2 peltohehtaaria käsittävälle viljelmälle. Nämä tilastoviljelmät on arvalla valittu Suomen kaikista viljelmistä vuodelta 1950 siten, että ne edustavat kaikkien eri maanviljelysseurojen alueita ja eri viljelmäsuuruusluokkia. Vastauksia saatiin $4446 \mathrm{kpl}$. eli $44.2 \%$ lähetettyjen tiedustelujen määrästä. Viljelmät on ryhmitelty peltoalan mukaan neljään suuruusluokkaan ja Suomi jaettu neljään 
tutkimusalueeseen, jotka olivat Etelä-alue (E), Keski-alue (K), Pohjois-alue (P) ja Lapin alue (L). Tulokset on esitetty näiden alueiden sekä koko maan keskiarvoina.

Tutkimuksen mukaan nykyisen viljelijän ikä on koko maassa keskimäärin 51.3 vuotta. Maan pohjoisosassa ovat viljelijät $1-3$ vuotta vanhempia kuin eteläSuomessa. Yli 60-vuotiaita viljelijöitä oli koko maassa $27.0 \%$ ja Lapin alueella $35.6 \%$.

Nykyisen viljelijän jälkeen aiotaan koko maassa $85.4 \%$ tiloista luovuttaa sukulaisille. Tilan myymistä suunnittelee $12.8 \%$ E-alueen, mutta vain $7.1 \% \mathrm{~L}$ alueen viljelijöistä. Viljelemättä jättäminen tulee kysymykseen vajaalla prosentilla E-alueen viljelmistä. Määrä kohoaa pohjoista kohden ja Lapissa se on $3.3 \%$. Samalla kun viljelmien keskimääräinen koko pienenee etelä-Suomesta pohjoiseen päin, lisääntyy perillisten kesken jaettavien tilojen osuus $18.9 \%$ :sta etelä-Suomessa $49.2 \%$ :iin Lapissa.

Viljelijäperheiden keskimääräinen lapsiluku koko maassa on $3.5 \mathrm{kpl}$. Lasten lukumäärä viljelmää kohden kasvaa siirryttäessä etelästä pohjoiseen. Lapissa se on $2.1 \mathrm{kpl}$. enemmän kuin etelä-Suomessa. Viljelijäperheiden lasten kokonaismäärästä on E-alueella $23.3 \%$ sellaisia lapsia, joiden koulunkäynti on rajoittunut kansakoulun suorittamiseen. Pohjoiseen päin mentäessä vastaava luku lisääntyy. Lapissa se on $35.9 \%$. Useimpien ammattikoulujen sekä oppikoulun suorittaminen, samoin opiskelu yliopistossa on P-alueella vähemmän yleistä kuin muualla. Oppikoulussa oli tiedusteluhetkellä $8.8 \%$ maan eteläosan viljelijäperheiden lapsista. P-alueella oli vastaava luku $4.1 \%$. Yliopistossa tai muussa korkeakoulussa opiskelevia tai niissä tutkinnon suorittaneita oli E-alueella $3.6 \%$ ja P-alueella $1.3 \%$ viljelijäperheiden lapsista.

Tiloja, joilla toimi koulunsa tai opintonsa päättäneitä lapsia maataloudessa tai siihen liittyvässä kotitaloudessa, oli E-alueella $55.1 \%$, K-alueella $60.9 \%$, Palueella $69.9 \%$, L-alueella $60.4 \%$ ja koko maassa $60.7 \%$ tilojen kokonaismäärästä. Tutkimuksessa on lisäksi selvitetty niiden perheiden määrät, joiden lapsia on muualla maatalouden palveluksessa (keskim. $4.1 \%$ ) sekä tapaukset, joissa joku koulussa olevista aikoo jäädä maatalouden palvelukseen (keskim. $13.7 \%$ ). Edellä mainitut ryhmät yhteensä osoittavat, kuinka suuri osa tiloista korkeintaan tulee säilymään nykyiseen viljelijäperheeseen kuuluvan hallussa seuraavan sukupolven aikana.

Kotoa siirtyneiden lasten osuus on P-alueella noin $17 \%$ ja muualla noin $20 \%$ koko lapsimäärästä. E-alueella toimii $17.3 \%$ ja muilla alueilla runsas neljäsosa siirtyneiden lasten määrästä muualla maa- tai metsätalouden palveluksessa.

Viljelijöiden käsityksen mukaan tärkein syy maaltapakoon on maatalouden huono kannattavuus. Verraten yleisiä syitä ovat myös haluttomuus tilan jakamiseen sekä sivuansioiden puute.

\section{KIRJALLISUUTTA}

(1) Autiotilatoimikunnan mietintö. S. I-II + 1-81 + 1-39. Helsinki 1957 .

(2) Мйкı, A. 1958. Maaltapako. Oma maa, s. 463-473. Porvoo.

(3) Redogörelse för regionala jordbruksplaneringen inom Gagnef 1949-1955. 67 s. + kartta. Mora 1955.

(4) Rāsãnen, M. 1959. Maaltapako ja maatilojemme hoidon jatkuvuus. Maatalous 52: $128-129$.

(5) Suomen virallinen tilasto III 46: 1-133. Helsinki. 
CONTINUITY OF FARM MANAGEMENT AND THE SO-CALLED RURAL EXODUS

\author{
Antti Mäki, Maire Honkanen and Matti Räsänen
}

\author{
Department of Agricultural Economics, University of Helsinki
}

The investigation is based on a questionnaire mailed in 1957 to some 10000 farms with a minimum of 2 hectares of arable land. These holdings were selected by lot from among all Finnish farms in 1950 to represent the districts of all the agricultural societies and the different sizes of the holdings. A total of 4446 replies were received, which is $\mathbf{4 4 . 2}$ per cent of the number of questionnaires mailed. The holdings were grouped by the tilled area into four classes and the whole country was divided into four investigation areas. These were the Southern area (E), the Central area (K), the Northern area (P) and the Lapland area (L). The results are given as means for these areas and for the country as a whole.

According to the investigation, the mean age of the present-day farmer in the country as a whole is 51.3 years. In the northern part of the country farmers are $1-3$ years older than in southern Finland. Farmers over 60 totalled 27.0 per cent in the country as a whole and 35.6 per cent in the area of Lapland.

85.4 per cent of all farms in the country are to be inherited by relatives after the decease of the present owner. In the E area, 12.8 per cent of the farmers plan to sell the farm, in the L area only 7.1 per cent. Less than one per cent of the farms of the E area come into the category of neglected holdings. The percentage rises northwards and is $\mathbf{3 . 3}$ in Lapland. At the same time as the average size of the farms diminishes on moving from southern Finland northwards, the proportion of farms to be divided among heirs increases from 18.9 per cent in southern Finland to 49.2 per cent in Lapland.

The average number of children in farming families is $\mathbf{3 . 5}$ in the country as a whole. The number of children per farm increases on moving northwards being 2.1 more in Lapland than in southern Finland. Of the total of children in farming families, 23.3 per cent in the E area are children whose school education is limited to attendance at elementary school. The percentage increases on advancing northward and is 35.9 in Lapland. Fewer children than elsewhere attend vocational schools and secondary school or study at a university in the $\mathrm{P}$ area. At the time of the inquiry, 8.8 per cent of the children of farming families in the southern part of Finland were attending secondary school. In the $\mathrm{P}$ area, the corresponding figure was 4.1 per cent. Youths attending or graduated from a university or other institute of higher learning accounted for 3.6 per cent of the children of farming families in the E area and for 1.3 per cent in the $\mathrm{P}$ area.

The percentage of farms which had children with completed schooling or studies engaged in farming or associated work on the home farm was 55.1 per cent in the $\mathrm{E}$ area, 60.9 per cent in the $\mathrm{K}$ area, 69.9 per cent in the $\mathrm{P}$ area and 60.4 per cent in the $\mathrm{L}$ area. For the country as a whole the corresponding percentage was $\mathbf{6 0 . 7}$. The investigation also provided information on the number of families whose children were employed on other work than farming (4.1 per cent on an average) and the cases in which one of the children still at school intended to continue working on the land (average 13.7 per cent). The above-mentioned groups taken together give the maximum number of farms that will remain in the possession of the same family during the next generation.

The proportion of children who had left the farm was about 17 per cent in the $\mathrm{P}$ area and elsewhere about 20 per cent of the total of children. In the E area 17.3 per cent, and in the other areas well over a fourth, of the number of children who had moved from home were employed elsewhere in agriculture or forestry.

In the farmer's view, the most important reason for the flight from the rural areas is the poor profitableness of farming. Other fairly common reasons are unwillingness to divide up the farm and lack of supplementary earnings. 